\title{
How well do terrestrial biosphere models simulate coarse-scale runoff in the contiguous United States?
}

C.R. Schwalm ${ }^{1,2, \dagger}$, D.N. Huntzinger ${ }^{2,3}$, R.B. Cook $^{4}$, Y. Wei ${ }^{4}$, I.T. Baker ${ }^{5}$, R.P. Neilson ${ }^{6}$, B.

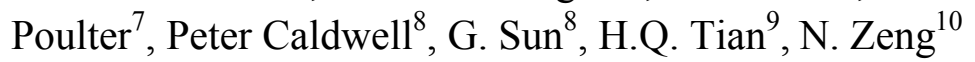

[1] Center for Ecosystem Science and Society, Northern Arizona University, Flagstaff, AZ 86011, USA

[2] School of Earth Sciences and Environmental Sustainability, Northern Arizona University, Flagstaff, AZ 86011, USA

[3] Department of Civil Engineering, Construction Management, and Environmental Engineering, Northern Arizona University, Flagstaff, AZ 86011, USA

[4] Environmental Sciences Division, Oak Ridge National Laboratory, Oak Ridge, TN 37831, USA

[5] Department of Atmospheric Sciences, Colorado State University, Fort Collins, CO 80523, USA

[6] Pacific Northwest Research Station, USDA Forest Service, Corvallis, OR 97331, USA

[7] Department of Ecology, Montana State University, Bozeman, MT 59717, USA

[8] Southern Research Station, USDA Forest Service, Raleigh, NC 27606, USA

[9] International Center for Climate and Global Change Research School of Forestry and Wildlife Sciences, Auburn University, Auburn 36849, AL, USA

[10] Department of Atmospheric and Oceanic Science, University of Maryland, College Park, MD 20742, USA

† Corresponding author: (Tel: +1-928-523-8413, Fax: +1-928-523-7423, christopher.schwalm@nau.edu)

\section{Abstract}

2 Significant changes in the water cycle are expected under current global environmental change.

3 Robust assessment of present-day water cycle dynamics at continental to global scales is

4 confounded by shortcomings in the observed record. Modeled assessments also yield conflicting

5 results which are linked to differences in model structure and simulation protocol. Here we

6 compare simulated gridded ( $1^{\circ}$ spatial resolution) runoff from six terrestrial biosphere models

7 (TBMs), seven reanalysis products, and one gridded surface station product in the contiguous

8 United States (CONUS) from 2001 to 2005. We evaluate the consistency of these 14 estimates

9 with stream gauge data, both as depleted flow and corrected for net withdrawals (2005 only), at 
10 the CONUS and water resource region scale, as well as examining similarity across TBMs and

11 reanalysis products at the grid cell scale. Mean runoff across all simulated products and regions

12 varies widely (range: 71 to $356 \mathrm{~mm} \mathrm{yr}^{-1}$ ) relative to observed continental-scale runoff (209 or

$13280 \mathrm{~mm} \mathrm{yr}^{-1}$ when corrected for net withdrawals). Across all 14 products 8 exhibit Nash-Sutcliffe

14 efficiency values in excess of 0.8 and three are within $10 \%$ of the observed value. Region-level

15 mismatch exhibits a weak pattern of overestimation in western and underestimation in eastern

16 regions -although two products are systematically biased across all regions- and largely scales

17 with water use. Although gridded composite TBM and reanalysis runoff show some regional

18 similarities, individual product values are highly variable. At the coarse scales used here we find

19 that progress in better constraining simulated runoff requires standardized forcing data and the

20 explicit incorporation of human effects (e.g., water withdrawals by source, fire, and land use

21 change).

22 1. Introduction

23 Water balance calculations are becoming increasingly important for Earth system studies and

24 link directly to the amount of reusable water available for wildland and managed environments,

25 as well as human society. Both a general intensification of the hydrological cycle (Schwalm et

26 al., 2011) and, more specifically, an increase in runoff are expected under climate change

27 (Gerten et al., 2008). While numerous attempts (e.g., Alkama et al., 2011; Dai et al., 2009;

28 Gerten et al., 2008; Haddeland et al., 2011; Milliman et al., 2008; Munier et al., 2012; Syed et

29 al., 2009; Walling \& Fang, 2003) have been made to observationally constrain continental to

30 global runoff values large uncertainties remain; linked to inter alia spatiotemporal gaps in the

31 observed record and the overall heterogeneity of discharge measurements. 
33 A standard approach to address inconsistent observational records is the use of modeling.

34 However, simulated runoff is similarly variable (e.g., Alkama et al., 2011; Gedney et al., 2006;

35 Haddeland et al., 2011; Shi et al., 2011). Furthermore, large variation in runoff persists even

36 when models use the same meteorological input data (Haddeland et al., 2011). A key source of

37 this ambiguity is the diversity in how models simulate runoff in relation to global environmental

38 change, e.g., changes in precipitation, temperature, net radiation, land cover/use, nitrogen

39 deposition, fire regime, atmospheric concentrations of greenhouse gases, and irrigation (Caldwell

40 et al., 2012; Gerten et al., 2008; Neilson, 1995; Sun et al., 2012). Model forcing data also plays a

41 significant role in simulated runoff magnitude, with the choice of precipitation dataset alone

42 altering simulated region-scale runoff estimates of up to $30 \%$ (Biemans et al., 2009).

43 Furthermore, uncertainty in precipitation fields (inter-product spread) may propagate to a similar

44 or greater magnitude of uncertainty in runoff estimates (Fekete et al., 2004).

46 As a first step to resolve ambiguity in simulated runoff, models must be confronted with

47 observational records. Thus, the objective of this study is to evaluate a suite of modeled runoff

48 estimates in a region with a dense network of stream gauges, the water resource regions (WRRs)

49 of the contiguous United States (CONUS). Specifically, we use TBM simulations from the

50 Regional and Continental Interim-Synthesis (RCIS); a synthesis activity part of the U.S. North

51 American Carbon Program (NACP) with emphasis on the 2000 to 2005 time period (Huntzinger

52 et al., 2012). To provide additional context for RCIS TBM runs we extend our intercomparison

53 with reanalysis- and surface station-based estimates of runoff for the same spatiotemporal

54 domain. Throughout this study we emphasize the coarse scales (from grid cell to CONUS) that

55 typify TBM use as opposed to pristine watersheds and finer scales. 


\section{Data and Methods}

57 We compare observed runoff to 14 modeled runoff estimates. Observed runoff is derived from

58 the $c .7,400$ currently operating stream gauges maintained by the United States Geological

59 Survey (USGS) ${ }^{1}$. This network of stream gauges is organized by hydrologic unit codes $\left(\mathrm{HUC}^{2}\right)$

60 using a standardized six-level nested hierarchy that, nationally for the United States, varies from

6121 water resource regions (WRR) at level one (also called 2-digit HUC or HUC2) to c. 160,000

62 subwatersheds at level $\operatorname{six}^{3}$. For this study the 18 WRRs in the CONUS domain (Figure 1) are

63 used.

64

65 Monthly WRR runoff is available directly from the USGS WaterWatch ${ }^{4}$ portal. The WRR values

66 are based on daily flow data collected at stream gauges, stream gauge drainage basins, and HUC

67 boundaries. Monthly runoff is computed for each basin by dividing average daily flow (scaled by

68 days per month) by basin drainage area. These stream gauge-specific values are assigned to the

69 target HUC level using area weighting and assuming runoff is uniform across each stream gauge

70 basin. Thus, the WRR values leverage the full network of currently operating stream gauges.

71

72 The gridded ( $1^{\circ}$ spatial resolution) monthly TBM runoff values (Table 1) span 2001 to 2005 on a

73 water year basis. A water year is the period from October 1 to September 30 with the water year

74 designation (e.g., 2005) corresponding to the year of the ending date. TBM output is taken from

75 the NACP RCIS (Huntzinger et al., 2012), as well as an additional TBM, WaSSI, that simulates

76 the same spatiotemporal domain as the RCIS but not gridded. The six TBM simulations, an

\footnotetext{
${ }^{1} \mathrm{http}: / /$ waterwatch.usgs.gov/public/flow_stats/dv01d.zip

${ }^{2}$ http://water.usgs.gov/GIS/huc.html

$3 \mathrm{ftp} / / / \mathrm{ftp}-\mathrm{fc} . \mathrm{sc}$.egov.usda.gov/NCGC/products/watershed/hu-standards.pdf

${ }^{4} \mathrm{http}: / /$ waterwatch.usgs.gov
} 
77 ensemble of opportunity (Allen \& Ingram, 2002), are comprised of model output generated from

78 ongoing NACP and related studies. While this precludes attributing model-data mismatch to

79 model structure and/or differences in driver data, it better mimics current practice as each run

80 represents the "best estimate" of runoff for each TBM. A further concern is the time period of the

81 TBM simulations. This five-year period limits the time horizon and resolution of the

82 intercomparison (all other products are multi-decadal), is not sufficient to derive climatological

83 mean runoff statistics, and could be biased by extreme events (although this bias would be

84 present in all products). However, our goal is to evaluate the ability of the off-the-shelf NACP

85 RCIS runs to simulate runoff during the RCIS study period. We make no claim that TBM

86 evaluations transfer to other areas or periods of interest but also would highlight the need to

87 understand the utility of such "as is" ensembles of opportunity regularly generated by the broader

88 land surface modeling community.

90 To contextualize the NACP RCIS runs we also evaluate runoff derived from a North America-

91 specific reanalysis, third generation reanalysis products from coupled models, and land-based

92 reanalysis products (Table 1):

93 1) Native runoff from the National Center for Environmental Prediction (NCEP) North 94 American Regional Reanalysis product (NARR; Mesinger et al., 2006);

95 2) runoff as NARR precipitation minus NARR evapotranspiration (hereafter NARR [P-E]);

96 3) runoff as scaled NARR precipitation minus NARR evapotranspiration (hereafter NARR

97 [GPCP]), where the scaling (Table 1) merges the spatial texturing of NARR with GPCP bias

98 corrections for wind, gauge wetting, and gauge evaporation (Wei et al., 2013); 
In addition to the seven variants of reanalyzed runoff we use an estimate of runoff derived from

111 monthly water-budget fields (Table 1) calculated by the Center for Climatic Research, 112 Department of Geography at the University of Delaware ${ }^{6}$. This estimate (hereafter UDel) is 113 based on surface station records of temperature and precipitation. Both are first interpolated in 114 space using Shepard's method and in time using climatologically aided interpolation (Willmott 115 \& Robeson, 1995). These interpolated estimates are then used as inputs in a modified 116 Thornthwaite water-budget equation, assuming a soil water holding capacity of $150 \mathrm{~mm}$, to 117 estimate evapotranspiration (Willmott et al., 1985). Evapotranspiration is subtracted from 118 precipitation to estimate runoff $\left(1^{\circ}\right.$ spatial resolution $)$.

4) native runoff from the NASA Modern Era Reanalysis for Research and Applications product (MERRA; Rienecker et al., 2011);

5) native runoff from MERRA LAND (Reichle et al., 2011), an off-line land-only replay of the MERRA land model with precipitation forced using native MERRA precipitation merged with the NOAA Climate Prediction Center gauge-based data product (Xie \& Arkin, 1996) and using the Fortuna-2.5 version of the catchment land surface model as opposed to the native MERRA version ${ }^{5}$; and

6) native runoff simulated by the Noah version 2.8 land surface model (Ek et al., 2003) driven by version 2 of both the North American Land Data Assimilation System (NLDAS; Xia et al., 2012) and the Global Land Data Assimilation System (GLDAS; Rodell et al., 2004). 
120 Before analysis, all runoff products are aggregated to annual values on a water year basis

121 (October to September) from 2001 to 2005, i.e., the temporal extent of NACP RCIS model runs.

122 We use annual values as none of the TBM runs evaluated include river routing and effectively

123 discharge all runoff into the ocean immediately. After integration in time, runoff is spatially

124 aggregated, apart from USGS values which are already WRR-level estimates. For the

125 comparison using WRRs, modeled runoff is aggregated to the relevant region (Figure 1); for the

126 CONUS-wide analysis, spatial aggregation is across all WRRs. We also compare TBMs (except

$127 \mathrm{WaSSI}$ ) and reanalysis products (including UDel) to each other at the $1^{\circ}$ by $1^{\circ}$ grid scale. For the

1282001 to 2005 period water withdrawal data is available for 2005 only (Barber et al., 2009;

129 Caldwell et al., 2012). We use this water use data to correct depleted USGS runoff to naturalized

130 flow, the quantity estimated by the 14 runoff products, to evaluate 2005 model-data agreement.

131 This correction is based on adding, by WRR, net withdrawals to reported USGS runoff. Model

132 skill is quantified using bias and Nash-Sutcliffe efficiencies (NSE; Nash \& Sutcliffe, 1970); the

133 latter metric ranges from negative infinity to unity where unity indicates perfect model-data

134 agreement.

\section{3. Results}

136 The reanalysis and UDel runoff values are in poor agreement with observed continental-scale

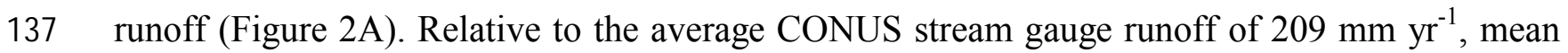

138 modeled runoff from 2001 to 2005 is $166 \mathrm{~mm} \mathrm{yr}^{-1}$ and $298 \mathrm{~mm} \mathrm{yr}^{-1}$ for the reanalyses and UDel

139 respectively. In a relative sense, the reanalysis products underestimate CONUS runoff by $c .25 \%$ 
140 while the annual runoff derived from the UDel product is almost 1.5 times greater than observed.

141 In contrast, the mean value across all six TBMs is within $25 \%\left(258 \mathrm{~mm} \mathrm{yr}^{-1}\right)$ of average stream

142 gauge runoff. In addition to being less consistent with observations, the variability (standard

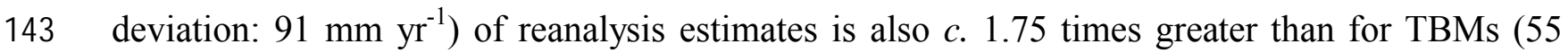

$\left.144 \mathrm{~mm} \mathrm{yr}^{-1}\right)$.

146 Normalizing runoff by precipitation, or runoff as a proportion of precipitation, can be viewed as

147 a control for the differences in precipitation data (Figure 2D). For USGS data we use

148 precipitation data not used in conjunction with any estimated runoff values, the Global

149 Precipitation Climatology Centre Full Data Reanalysis (GPCC ${ }^{7}$; Schneider et al., 2011). While

150 normalization does decrease interannual variability for all estimated products except SiB3.1

151 (Figure 2B), the general pattern of overestimation vs. underestimation remains largely

152 unchanged. As another means to control for the differences in precipitation data we adjust runoff

153 to match a precipitation standard. The adjustment is based on multiplying modeled runoff by the

154 ratio of model-specific precipitation to the independent GPCC product. Similar to normalization

155 this results in only minor changes (Figure 2C). A large discrepancy between runoff and adjusted

156 runoff would suggest that precipitation data differences confound simulated runoff. However,

157 this is not apparent for either GPCC (Figure 2D) or the forcing datasets used (not shown).

159 We acknowledge that normalization or adjustment cannot render an ensemble of opportunity into 160 a standardized ensemble, as other non-standardized determinants of model output and skill, e.g., 161 boundary conditions, spin-up procedures (Huntzinger et al., 2013), and analysis structure 162 (Schwalm et al., 2013), are not amenable to a simple adjustment. However, the minimal changes

\footnotetext{
${ }^{7} \mathrm{ftp} / / / \mathrm{ftp} . d w d . d e / p u b /$ data/gpcc/html/fulldata_v6_doi_download.html
} 
163 in estimated runoff values strongly suggest that the variability in precipitation forcing datasets

164 (Figure 2D) does not confound model-data mismatch. Therefore, we limit our discussion to 165 unadjusted runoff.

167 The region level mismatch between stream gauge and modeled runoff implies a geographic

168 divide; WRRs east of and including the Mississippi river are generally underestimated whereas

169 western WRRs are overpredicted (Figure 3; Table A1). However, SLand systematically

170 overpredicts all regions. The remaining TBMs also show a tendency toward positive biases,

171 especially in the Rio Grande and Lower Colorado WRRs where SiB3.1 overestimates both by a

172 factor of c. 7 (Figure 3). Among the reanalysis and UDel products, MERRA underestimates

173 runoff in every WRR while NLDAS overestimates all and UDel all but two (New England and

174 Mid-Atlantic). Furthermore, there is no relationship between mismatch and WRR size (not 175 shown).

177 The weak east-west pattern suggests that water use, which is generally larger in the western 178 CONUS (Table 1), may degrade consistency with USGS stream gauge observations (Caldwell et 179 al., 2012). To investigate this potential dependency we use corrected USGS runoff values and an 180 index of water use, i.e., net withdrawals normalized by corrected USGS runoff. Here, most ( 8 of 181 14) products show a dependency $(p<0.05)$ of relative bias on the index of water use. LPJ-wsl, 182 MERRA, MERRA LAND, NARR, SLand, and WaSSI show no relationship ( $p>0.2$ but $p=$ 1830.11 for NARR). More generally, relative bias is highly sensitive to increases in water use across 184 all products (Figure 4). For every 0.10 increase in the water use index, relative bias increases, on 185 average, by $0.25(p<0.0001)$. Also, WRRs with higher index values are not only preferentially 
overestimated but also show a greater spread in estimated values. The increase in relative bias

187 with increasing water use similarly holds when using a given withdrawal source (e.g., surface vs.

188 groundwater withdrawals and eight standard categories [Barber et al., 2009]) to index water use.

189 Only industrial and thermoelectric power water use have negative sensitivities (-0.2 and -1.6

190 respectively). Also, relative bias is more sensitive to groundwater (0.28) than surface water

191 (0.18) withdrawals.

192

193 Using corrected USGS runoff we find that eight of the 14 products evaluated exceed the 194 customary NSE threshold for "good" model-data agreement ( $\geq 0.8$ ) (Figure 5). This includes 195 four of the six TBMs evaluated. Furthermore, TBMs exhibit a mean NSE of 0.78 vs. 0.61 for

196 reanalyses products (although the land-based reanalysis products have NSE values of 0.85 and 197 0.86) and 0.94 for the UDel product. These NSE values are higher than when using depleted 198 USGS runoff values as comparator; where only six of the 14 products exceed the 0.8 threshold. 199 Products showing less skill, i.e., lower NSE values, exhibit the largest gains in NSE when 200 switching to corrected USGS values (not shown). This does not hold for MC1 and WaSSI where 201 using corrected USGS values results in a 0.08 and 0.01 loss in NSE respectively.

203 While mean gridded runoff from TBMs and reanalysis products (including UDel) are within 6 $204 \mathrm{~mm} \mathrm{month}{ }^{-1}$ or c. $25 \%$ (22 and $17 \mathrm{~mm} \mathrm{month}^{-1}$ for TBMs and reanalysis respectively), these 205 composite values (Figure 6) mask highly variable individual product estimates of runoff and 206 spatial gradients in grid cell level differences (Figure A1). Across the Great Plains and western 207 CONUS both TBMs and reanalysis products show similar means. Despite this broad similarity, 208 reanalysis products tend to simulate slightly more runoff west of the Mississippi (save the Pacific 
209 Northwest), with the largest relative differences located in the Southwest. In contrast, grid cells

210 in six eastern WRRs (Lower Mississippi, Ohio, Tennessee, South Atlantic-Gulf, Mid-Atlantic,

211 and New England) and the lower Great Lakes regions are not in agreement, with TBMs

212 simulating more runoff than reanalysis products and UDel. The spread in reanalysis runoff

213 (coefficient of variation) averages $79 \%$ in space with the highest values in the Southwest (Figure

214 6). TBMs also exhibit a large degree of spread (mean coefficient of variation: 53\%) with the

215 largest variability in the Mountain West and Southwest.

\section{4. Discussion}

217 This study provides an evaluation of model and observationally derived continental, WRR, and 218 grid cell-scale surface annual runoff in the CONUS domain from 2001 to 2005. At the region-

219 scale, the 14 products are consistent in their lack of agreement with stream gauge values. There 220 is neither a coherent spatial pattern across WRRs, nor a region where all products exhibit a 221 uniformly high (or low) level of consistency with stream gauge data. General agreement is seen 222 only at the grid cell level in composite means (averages across all TBMs or reanalysis products) 223 west of the Mississippi, but individual products are highly variable. Nonetheless, we can use

224 CONUS-wide runoff to place the 14 products into three generic tiers based on model skill, with 225 the first tier products generally agreeing the closest with USGS observations.

227 The first tier products comprise TBMs (DLEM, LPJ-wsl, SiB3.1, WaSSI), land-based reanalyses 228 (GLDAS, NLDAS), and precipitation minus evapotranspiration estimates (NARR [GPCP], 229 UDel). All of these products show "good" model-data agreement (NSE $\geq 0.8$ ) and generally low 230 relative biases ( $\leq 0.15$ and 0.25 in magnitude for TBMs and other first tier products respectively)

231 for CONUS-wide runoff. The second tier of skill is occupied by NARR [P-E] and MC1. These 
232 show intermediate NSE values of $c .0 .7$ and negative relative biases $\leq 0.2$. It is noteworthy that

233 the products based on based on precipitation minus evapotranspiration (UDel, NARR [P-E], and

234 NARR [GPCP]) have reasonable skill levels; NSE range: 0.73 to 0.94 and relative biases $\leq 0.2$.

235 Compared to TBMs, which require substantial infrastructure to implement and run, precipitation

236 minus evapotranspiration is trivial to estimate using readily accessible data products suggesting

237 utility in large-scale diagnostic runoff studies.

238

239 The lowest tier consisting of reanalysis from coupled models (MERRA, MERRA LAND, and

240 NARR) and SLand exhibits little to no skill (NSE range: 0.15 to 0.55 ) with the three reanalysis

241 products biased low and SLand high. These patterns hold when either uncorrected or corrected

242 USGS runoff is used as comparator. The underestimation by NARR has been previously

243 documented using both CONUS River Forecast Center regions (Sheffield et al., 2012) and the

244 Mississippi River basin (Kumar \& Merwade, 2011). In contrast, both MERRA variants have

245 shown higher model skill relative to USGS data (Reichle et al., 2011) than in this study.

246 Methodological differences in evaluating MERRA and MERRA LAND skill (e.g., scale

247 mismatch of watersheds, different temporal extent and granularity) preclude reconciliation of

248 these findings although both studies show MERRA LAND outperforming MERRA.

250 Identifying the root causes of model-data mismatch in runoff estimates is an ongoing challenge,

251 especially for short-term ensembles of opportunity like the NACP RCIS. Such ensembles do not

252 control for possible confounding factors such as forcing data (Biemans et al., 2009) and

253 simulation protocol (Huntzinger et al., 2013). Furthermore, while USGS runoff can be corrected

254 for water withdrawals -to better mimic the 14 products evaluated here- the correction is 
255 imprecise. Water use estimates for some withdrawal sources are based on ancillary data across

256 multiple years (Barber et al., 2009); thus degrading model-data intercomparison as a function of

257 time. In addition, USGS withdrawal data does not include water use for hydroelectric power

258 generation and reclaimed wastewater (an important water source for thermoelectric power

259 generation in arid CONUS regions) (Barber et al., 2009). Similarly, mining, although a standard

260 source category, does not account for all mining-related activities; aquifer dewatering, water use

261 for smelting, refining petroleum, or slurry pipeline operations are excluded (Barber et al., 2009).

262

263 Beyond this unspecified but known water use, it is not a given that all withdrawals decrease

264 runoff. The net change in runoff depends on surface-subsurface interactions (Leung et al., 2010)

265 as well as withdrawal sources, which may have contrasting impacts on runoff (Leng et al., 2014).

266 As an example, ground water mining may act to increase runoff assuming the aquifer source is

267 not connected to surface water (Caldwell et al., 2012). In this study industrial and thermoelectric

268 power water use are shown to increase runoff, for industrial use this applies for both ground and

269 surface water separately as well. Runoff may also increase due to fire (Certini et al., 2005;

270 Verkaik et al., 2013) and land use change (Foley et al., 2005). None of these factors are tracked

271 explicitly by any product.

\section{5. Conclusions}

273 The TBMs examined here are, in general, able to reproduce observed patterns in CONUS-wide

274 runoff over the 2001 to 2005 analysis period. However, several products exhibit profound biases

275 and spatial heterogeneity in model skill. Diagnosing mismatch between stream gauge runoff and

276 any given product is confounded by their coarse scale and off-the-shelf nature. Runoff is

277 fundamentally a process that occurs on the catchment scale and multiple catchments within a 
278 large WRR may act in a compensatory manner that is not resolvable at a $1^{\circ}$ spatial resolution or

279 regional scale. Similarly, mismatch may also be influenced by the choice of forcing data used in

280 a particular TBM. As such it is difficult to attribute differences between simulated and observed

281 values solely to intrinsic characteristics of the models themselves. While this suggests that a

282 constrained ensemble (Huntzinger et al., 2013) is preferable to an ensemble of opportunity it also

283 reveals a clear dilemma: Even though several factors that may impact model-data mismatch are

284 only resolvable at finer scales, this does not obviate the need to evaluate runoff simulated at

285 coarser scales for ensembles of opportunity (such as the NACP RCIS).

286

287 A further complication is the tendency of several products, especially the TBMs, to exhibit the

288 "right answers for the wrong reasons" (Kirchner, 2006). This is most visible using uncorrected

289 USGS runoff for western WRRs with high water use, e.g., Rio Grande. That is, TBM estimates

290 show consistency with depleted USGS stream gauge data without explicit consideration of

291 anthropogenic perturbations to the water cycle (e.g., land use change, fire effects, and water

292 withdrawals). This compensatory effect can be related to model formulation, e.g., bulk

293 parameters compensating for a lack of physically-based equations at relevant scales (Kirchner,

294 2006), or overall complexity in large heterogeneous systems at coarser scales as studied here

295 (McDonnell et al., 2007). Alternatively, model formulation of those processes included can 296 compensate for those processes excluded.

298 For TBMs specifically, contrasting model skill and model spread for the carbon and water cycles 299 offers a bridge between terrestrial and hydrological research. Model-model (Huntzinger et al., 300 2013) and model-data (Rackza et al., 2013) carbon flux intercomparisons have been conducted 
301 using NACP RCIS runs. Although each intercomparison varies in analytical framework both can

302 be contrasted with TBM outputs evaluated in this study. Given the lack of gridded observational

303 products that can serve as unambiguous references (Luo et al., 2012) we examine model spread,

304 i.e., variability across the TBM ensemble (calculated as range normalized by mean value

305 expressed as a percentage). This also allows diverse land surface processes to be compared

306 directly. Using grid cells with co-located flux towers (Raczka et al., 2013) and the full North

307 American domain (Huntzinger et al., 2012) TBM carbon cycle variability ranges from $81 \%$ to

$308387 \%$ (Figure 7). For runoff the corresponding CONUS-wide variability is markedly lower (=

$30956 \%$ ). Although the water and carbon cycles are tightly coupled, this suggests that the limited

310 resources available for TBM development should preferentially target key constraints of the

311 carbon cycle. Ultimately, improving the characterization of the carbon cycle will improve model-

312 data agreement for the water cycle and vice versa. However, model-model and model-data

313 studies that simultaneously address both the water and carbon cycles are a necessary

314 precondition to realize this goal.

316 More generally, there is a pressing need to confront TBMs (indeed, all simulated products) with

317 observations at multiple scales (Gerten, 2013), particularly the characteristic scale at which the

318 process occurs, such as the catchment scale for runoff. Furthermore, intercomparisons of model

319 structure relative to skill (Schwalm et al., 2010) will help inform model development and reduce

320 ensemble spread and error. For runoff specifically, the use of standardized forcing data

321 (especially for TBMs; Wei et al., 2013), the explicit incorporation of human effects (e.g., water

322 cycle management, fire, land use change), higher quality water withdrawals data (Caldwell et al.,

323 2012), more realism in the representation of subgrid variability, and river routing schemes are all 
necessary to improve model-data agreement. Large-resource model-intercomparison projects that

325

use a constrained protocol (e.g., Huntzinger et al., 2013) hold great promise in furthering our understanding of Earth system dynamics at multiple scales and provide a framework to evaluate model skill and spread of carbon and water cycles simultaneously.

\section{Acknowledgements}

Support for this activity came from the US National Aeronautics and Space Administration (NASA) Terrestrial Ecology Program (NNH10AN68I and NNX11AO08A) and from the Terrestrial Ecosystem Science Focus Area at the Office of Biological and Environmental Research, US Department of Energy (DOE). Oak Ridge National Laboratory is managed by UTBattelle for DOE under contract DE-AC05-00OR22725. IB was sponsored by the National Science Foundation (NSF) (ATM-0425247, AGS-0425247-13 and AGS1049041), the Department of Commerce/National Oceanic and Atmospheric Administration (NA08AR4320893), NASA (NNX06AC75G, NNX08AM56G, NNX12AP86G, NNX10AT41G, and NNX11AB87G), DOE (DE-FG02-06ER64317), and the National Institute for Climate Change Research (MTU050516Z14). PC and GS were partially supported by the NSF EaSM program (AGS-1049200) at North Carolina State University. HT was supported by the NASA Interdisciplinary Science Program (NNX11AD47G and NNX10AU06G). We thank Mac Post for his contributions to this research. This is a contribution of the North American Carbon Program.

\section{References}

Alkama, R., B. Decharme, H. Douville, A. Ribes, 2011: Trends in Global and Basin-Scale Runoff over the Late Twentieth Century: Methodological Issues and Sources of Uncertainty. J. Climate, 24, 3000-3014. doi: http://dx.doi.org/10.1175/2010JCLI3921.1

Allen, M. R., \& Ingram, W. J. (2002). Constraints on future changes in climate and the hydrologic cycle. Nature, 419(6903), 224-232.

Bachelet, Lenihan, Daly, Neilson, Ojima, \& Parton. MC1: A Dynamic Vegetation Model for Estimating the Distribution of Vegetation and Associated Ecosystem Fluxes of Carbon, Nutrients, and Water. USFS GTR PNW-GTR-508, June 2001

Baker, I. T., Denning, A. S., and Stockli, R.: North American gross primary productivity: regional characterization and interannual variability, Tellus Ser. B, 62B, 533-549, doi:10.1111/j.1600-0889.2010.00492.x, 2010.

Barber, N. L., Hutson, S. S., Linsey, K. S., Lovelace, J. K., \& Maupin, M. A. (2009). Estimated use of water in the United States in 2005 (p. 52). Reston, VA: US Geological Survey.

Biemans, H., Hutjes, R., Kabat, P., Strengers, B., Gerten, D., Rost, S., 2009. Impacts of precipitation uncertainty on discharge calculations for main river basins. Journal of Hydrometeorology 10, 1011-1025. 
Caldwell, P. V., Sun, G., McNulty, S. G., Cohen, E. C., and Moore Myers, J. A.: Impacts of impervious cover, water withdrawals, and climate change on river flows in the conterminous US, Hydrol. Earth Syst. Sci., 16, 2839-2857, doi:10.5194/hess-16-2839-2012, 2012.

Certini, G. (2005). Effects of fire on properties of forest soils: a review. Oecologia, 143(1), 1-10.

Chen, M., P. Xie, J. E. Janowiak, and P. A. Arkin, 2002: Global Land Precipitation: A 50-yr Monthly Analysis Based on Gauge Observations, J. of Hydrometeorology, 3, 249-266.

Dai, A., T. Qian, K. E. Trenberth, and J. D Milliman, 2009: Changes in continental freshwater discharge from 1948-2004. J. Climate, 22, 2773-2791.

Ek, M. B., K. E. Mitchell, Y. Lin, E. Rogers, P. Grunman, V. Koren, G. Gayno, and J. D. Tarpley, 2003. Implementation of Noah land surface model advances in the National Centers for Environmental Prediction operational mesoscale Eta model. J. Geophys. Res., 108, 8851, doi:10.1029/2002JD003296.

Fekete, B.M., Vörösmarty, C.J., Roads, J.O., Willmott, C.J., 2004. Uncertainties in precipitation and their impacts on runoff estimates. J. Climate 17, 294-304.

Foley, J. A., DeFries, R., Asner, G. P., Barford, C., Bonan, G., Carpenter, S. R., ... \& Snyder, P. K. (2005). Global consequences of land use. Science, 309(5734), 570-574.

Gedney, N., Cox, P.M., Betts, R.A., Boucher, O., Huntingford, C. and Stott, P.A. 2006. Detection of a direct carbon dioxide effect in continental river runoff records. Nature 439: 835838.

Gerten D, Schaphoff S, Haberlandt U et al. (2004) Terrestrial vegetation and water balance hydrological evaluation of a dynamic global vegetation model. Journal of Hydrology, 286, 249270

Gerten, D., S. Rost, W. von Bloh, and W. Lucht (2008), Causes of change in 20th century global river discharge, Geophys. Res. Lett., 35, L20405, doi:10.1029/2008GL035258.

Gerten, D. (2013). A vital link: water and vegetation in the Anthropocene. Hydrology \& Earth System Sciences, 17(10).

Haddeland, I., Clark, D. B., Franssen, W., Ludwig, F., Vo, F., Arnell, N. W., ... \& Polcher, J. (2011). Multimodel Estimate of the Global Terrestrial Water Balance: Setup and First Results. Journal of Hydrometeorology, 12(5).

Huffman, G. J., R. F. Adler, D. T. Bolvin, and G. Gu (2009), Improving the global precipitation record: GPCP Version 2.1, Geophys. Res. Lett., 36, L17808, doi:10.1029/2009GL040000.

Huntzinger D.N., W. Post, A. Michalak, Y. Wei, A. Jacobson, T.O. West, I. Baker, J. Chen, K. Davis, D. Hayes, F. Hoffman, A. Jain, S. Liu, D. McGuire, R. Neilson, B. Raczka, B. Poulter, H. 
Tian, P. Thornton, E. Tomelleri, N. Viovy, J. Xiao, N. Zeng, M. Zhao, and R. Cook. North American Carbon Project (NACP) Regional Interim Synthesis: Terrestrial Biospheric Model Intercomparison. (2012) Ecological Modelling 232:144-157. doi:10.1016/j.ecolmodel.2012.02.004

Huntzinger, D. N., Schwalm, C., Michalak, A. M., Schaefer, K., King, A. W., Wei, Y., Jacobson, A., Liu, S., Cook, R. B., Post, W. M., Berthier, G., Hayes, D., Huang, M., Ito, A., Lei, H., Lu, C., Mao, J., Peng, C. H., Peng, S., Poulter, B., Riccuito, D., Shi, X., Tian, H., Wang, W., Zeng, N., Zhao, F., and Zhu, Q.: The North American Carbon Program Multi-scale synthesis and Terrestrial Model Intercomparison Project - Part 1: Overview and experimental design, Geosci. Model Dev. Discuss., 6, 2121-2133, doi:10.5194/gmd-6-2121-2013.

Kanamitsu, M., Ebisuzaki, W., Woollen, J., Yang, S.-K., Hnilo, J. J. and co-authors. 2002. NCEP-DOE AMIP-II Reanalysis (R-2). Bull. Am. Meterol. Soc. 83(11), 1631-1643.

Kirchner, J. W. (2006). Getting the right answers for the right reasons: Linking measurements, analyses, and models to advance the science of hydrology. Water Resources Research, 42(3).

Koster, R.D., Suarez, M.J., Ducharne, A., Stieglitz, M., Kumar, P., 2000. A catchment-based approach to modeling land surface processes in a general circulation model. 1. Model structure. J. Geophys. Res. 105, 24809-24822

Kumar, S., and V. Merwade (2011), Evaluation of NARR and CLM3.5 outputs for surface water and energy budgets in the Mississippi River Basin, J. Geophys. Res., 116, D08115, doi:10.1029/2010JD014909.

Leng G, M Huang, Q Tang, H Gao, and LYR Leung. 2014. "Modeling the Effects of Groundwater-fed Irrigation on Terrestrial Hydrology over the Conterminous United States." Journal of Hydrometeorology 15(3):957-972. doi:http://dx.doi.org/10.1175/JHM-D-13-049.1.

Leung LYR, M Huang, Y Qian, and X Liang. 2010. "Climate-Soil-Vegetation Control on Groundwater Table Dynamics and its Feedbacks in a Climate Model." Climate Dynamics 36(12):57-81. doi:10.1007/s00382-010-0746-x.

Liu, M., H. Tian, C. Lu, X. Xu, G. Chen, W. Ren. 2012. Effects of Multiple Environment Stresses on Evapotranspiration and Runoff over the Eastern China. Journal of Hydrology Vol 426-427, 39-54. http://dx.doi.org/10.1016/j.jhydrol.2012.01.009.

McDonnell, J. J., Sivapalan, M., Vaché, K., Dunn, S., Grant, G., Haggerty, R., ... \& Weiler, M. (2007). Moving beyond heterogeneity and process complexity: A new vision for watershed hydrology. Water Resources Research, 43(7).

Mesinger, F., et al. (2006), North American regional reanalysis, Bull. Am. Meteorol. Soc., 87, $343-360$. 
Milliman, J. D., K. L. Farnsworth, P. D. Jones, K. H. Xu, and L. C. Smith, 2008: Climatic and anthropogenic factors affecting river discharge to the global ocean, 1951-2000. Global Planet. Change, 62, 187-194.

Munier, S., Palanisamy, H., Maisongrande, P., Cazenave, A., \& Wood, E. F. (2012). Global runoff anomalies over 1993-2009 estimated from coupled Land--Ocean--Atmosphere water budgets and its relation with climate variability. Hydrology \& Earth System Sciences, 16(10).

Nash, J., \& Sutcliffe, J. V. (1970). River flow forecasting through conceptual models part I-A discussion of principles. Journal of hydrology, 10(3), 282-290.

Neilson RP 1995. A Model for Predicting Continental-Scale Vegetation Distribution and Water Balance. Ecological Applications 5:362-385. http://dx.doi.org/10.2307/1942028.

Raczka, Brett M., Kenneth J. Davis, Deborah Huntzinger, Ronald P. Neilson, Benjamin Poulter, Andrew D. Richardson, Jingfeng Xiao, Ian Baker, Philippe Ciais, Trevor F. Keenan, Beverly Law, Wilfred M. Post, Daniel Ricciuto, Kevin Schaefer, Hanqin Tian, Enrico Tomelleri, Hans Verbeeck, and Nicolas Viovy 2013. Evaluation of continental carbon cycle simulations with North American flux tower observations. Ecological Monographs 83:531-556. http://dx.doi.org/10.1890/12-0893.1.

Reichle, Rolf H., Randal D. Koster, Gabriëlle J. M. De Lannoy, Barton A. Forman, Qing Liu, Sarith P. P. Mahanama, Ally Touré, 2011: Assessment and Enhancement of MERRA Land Surface Hydrology Estimates. J. Climate, 24, 6322-6338. doi: http://dx.doi.org/10.1175/JCLI-D10-05033.1

Rienecker, Michele M., Max J. Suarez, Ronald Gelaro, et al., 2011. MERRA - NASA's ModernEra Retrospective Analysis for Research and Applications. Journal of Climate, Vol. 24, Iss. 14, pp. 3624-3648.

Rodell, M., P. R. Houser, U. Jambor, J. Gottschalck, K. Mitchell, C.-J. Meng, K. Arsenault, B. Cosgrove, J. Radakovich, M. Bosilovich, J. K. Entin, J. P. Walker, D. Lohmann, and D. Toll, 2004. The Global Land Data Assimilation System, Bull. Amer. Meteor. Soc., 85(3): 381-394.

Schaake, J. C., V. I. Koren, Q.-Y. Duan, K. Mitchell, and F. Chen, 1996: Simple water balance model for estimating runoff at different spatial and temporal scales. J. Geophys. Res., 101, 74617475 .

Sheffield, J., G. Goteti, and E. F. Wood, 2006: Development of a 50-yr high-resolution global dataset of meteorological forcings for land surface modeling, J. Climate, 19 (13), 3088-3111.

Sheffield, Justin, Ben Livneh, Eric F. Wood, 2012: Representation of Terrestrial Hydrology and Large-Scale Drought of the Continental United States from the North American Regional Reanalysis. J. Hydrometeor, 13, 856-876. doi: http://dx.doi.org/10.1175/JHM-D-11-065.1. 
Schneider, Udo; Becker, Andreas; Finger, Peter; Meyer-Christoffer, Anja; Rudolf, Bruno; Ziese, Markus (2011): GPCC Full Data Reanalysis Version 6.0 at $1.0^{\circ}$ : Monthly Land-Surface Precipitation from Rain-Gauges built on GTS-based and Historic Data. DOI: 10.5676/DWD_GPCC/FD_M_V6_100.

Schwalm C.R., Williams C.A., Schaefer K., Anderson R., Arain M.A., Baker I., et al. A modeldata intercomparison of $\mathrm{CO} 2$ exchange across North America: Results from the North American Carbon Program site synthesis. (2010) Journal of Geophysical Research-Biogeosciences. 2010; 115: doi10.1029/2009JG001229.

Schwalm CR, Williams CA, Schaefer KM (2011) Carbon consequences of global hydrologic change, 1948-2009. J. Geophys. Res., 116, G03042, doi:10.1029/2011JG001674.

Schwalm, C. R., Huntzinger, D. N., Michalak, A. M., Fisher, J. B., Kimball, J. S., Mueller, B., ... \& Zhang, Y. (2013). Sensitivity of inferred climate model skill to evaluation decisions: a case study using CMIP5 evapotranspiration. Environmental Research Letters, 8(2), 024028.

Shi, X., J. Mao, P. E. Thornton, F. M. Hoffman, and W. M. Post (2011), The impact of climate, $\mathrm{CO} 2$, nitrogen deposition and land use change on simulated contemporary global river flow, Geophys . Res. Lett., 38, L08704, doi:10.1029/2011GL046773.

Sitch, S., Smith, B., Prentice, I. C., Arneth, A., Bondeau, A., Cramer, W., ... \& Venevsky, S. (2003). Evaluation of ecosystem dynamics, plant geography and terrestrial carbon cycling in the LPJ dynamic global vegetation model. Global Change Biology, 9(2), 161-185.

Sun, G., P. Caldwell, A. Noormets, E. Cohen, S.G. McNulty, E. Treasure, J.-C. Domec, Q. Mu, J. Xiao, R. John, and J. Chen. 2011. Upscaling Key Ecosystem Functions across the Conterminous United States by a Water-Centric Ecosystem Model. Journal of Geophysical Research: 116, G00J05, doi:10.1029/2010JG001573.

Syed, T. H., Famiglietti, J. S., Chambers, D. P., Willis, J. K., \& Hilburn, K. (2010). Satellitebased global-ocean mass balance estimates of interannual variability and emerging trends in continental freshwater discharge. Proceedings of the National Academy of Sciences, 107(42), 17916-17921.

Tian H, Chen G, Liu M, Zhang C, Sun G, Lu C, Xu X, Ren W, Pan S, Chappelka A. 2010. Model estimates of ecosystem net Primary productivity, evapotranspiration, and water use efficiency in the southern United States during 1895-2007. Forest Ecology and Management 259, 1311-1327. doi:10.1016/j.foreco.2009.10.009.

Verkaik, I., Rieradevall, M., Cooper, S. D., Melack, J. M., Dudley, T. L., \& Prat, N. (2013). Fire as a disturbance in Mediterranean climate streams. Hydrobiologia, 719(1), 353-382.

Walling, D.E. and Fang, D. 2003. Recent trends in the suspended sediment loads of the world's rivers. Global and Planetary Change 39: 111-126. 
548 Wei Y, Liu S, Huntzinger DN, Michalak AM, Viovy N, Post WM, Schwalm CR et al (2013) The 549 North American Carbon Program Multi-scale Synthesis and Terrestrial Model Intercomparison 550 Project - Part 2: Environmental driver data. Geosci. Model Dev. Discuss., 6, 5375-5422, 551 doi:10.5194/gmdd-6-5375-2013.

552

Willmott, C. J., C. M. Rowe, and Y. Mintz, (1985) Climatology of the Terrestrial Seasonal Water Cycle. Journal of Climatology, 5, 589-606.

555

556

557

558

559

Willmott, C. J. and S. M. Robeson (1995) Climatologically Aided Interpolation (CAI) of Terrestrial Air Temperature. International Journal of Climatology, 15, 221-229.

Xia, Y., Mitchell, K., Ek, M., Sheffield, J., Cosgrove, B., Wood, E., ... \& Mocko, D. (2012).

Continental-scale water and energy flux analysis and validation for the North American Land

model products. Journal of Geophysical Research: Atmospheres (1984-2012), 117(D3).

Xie P., and P. A. Arkin, 1996: Global precipitation: a 17-year monthly analysis based on gauge observations, satellite estimates, and numerical model outputs. Bull. Amer. Meteor. Soc., 78, $566 \quad 2539-2558$.

Zeng, N., J. D. Neelin, and C. Chou, 2000: The first quasi-equilibrium tropical circulation 569 model-implementation and simulation. J. Atmos. Sci., 57, 1767-1796. 
Tables

Table 1. Summary of runoff algorithms for modeled products. All products are monthly and resampled to $1^{\circ}$ spatial resolution for the CONUS domain; WaSSI runoff available only in ungridded format at the 8-digit sub-basin level.

\begin{tabular}{|c|c|c|c|}
\hline Model & Algorithm & Precipitation & Citation \\
\hline DLEM & $\begin{array}{l}\text { Runoff curve number method; function of effective precipitation } \\
\text { (precipitation minus interception, plus snow melt), potential maximum } \\
\text { soil moisture retention after runoff, and antecedent water in the soil } \\
\text { column. Soil water in excess of saturation in the first soil layers } \\
\text { becomes runoff. }\end{array}$ & NARR & $\begin{array}{l}\text { Liu et al. (2012); } \\
\text { Tian et al. (2010) }\end{array}$ \\
\hline LPJ-wsl & $\begin{array}{l}\text { Sum of surface runoff from the top soil layer, subsurface runoff from } \\
\text { the lower soil layer, and water percolating down through the lower } \\
\text { soil layer. The surface and subsurface runoff are defined as the excess } \\
\text { water above field capacity of the top and lower soil layers. }\end{array}$ & CRU-TS $3.0^{1}$ & $\begin{array}{l}\text { Gerten et al. (2004); } \\
\text { Sitch et al. (2003) }\end{array}$ \\
\hline $\mathrm{MC1}$ & $\begin{array}{l}\text { Sum of surface runoff, macropore (rapid through-flow via roots, } \\
\text { cracks, etc.) flow, rapid through-flow and baseflow. Baseflow is a } \\
\text { fraction of precipitation as modified by losses to transpiration or direct } \\
\text { percolation by soil layer. Losses to transpiration are driven by a } \\
\text { simplified version of Penmon-Montieth and transpiration by soil } \\
\text { moisture factor for each plant functional type. }\end{array}$ & PRISM $^{2}$ & Bachelet et al. (2001) \\
\hline $\mathrm{SiB} 3.1$ & $\begin{array}{l}\text { Precipitation (scaled to GPCP) minus evapotranspiration. SiB3.1 } \\
\text { natively calculates runoff using a defined allowable surface } \\
\text { interception storage (puddle) depth, which accumulates as } \\
\text { precipitation strikes the ground directly or runs off from the canopy. } \\
\text { There is a maximum allowable puddle depth; any water accumulating } \\
\text { above this is transferred to runoff, and is immediately in the ocean. As } \\
\text { native runoff is unphysical }(\rightarrow 0) \text { scaled precipitation minus } \\
\text { evapotranspiration is used instead. }\end{array}$ & $\begin{array}{l}\text { NCEP } I^{3} \\
\text { (precipitation scaled } \\
\text { to } \mathrm{GPCP}^{4} \text { ) }\end{array}$ & Baker et al. (2010) \\
\hline SLand & $\begin{array}{l}\text { Sum of surface and subsurface runoff. Surface runoff is precipitation } \\
\text { minus interception loss scaled by a non-linear function of relative soil } \\
\text { wetness. Subsurface runoff is a nonlinear function of relative soil } \\
\text { wetness and subsurface runoff at saturation. SLand is the land surface } \\
\text { model component of the dynamic vegetation/carbon model VEGAS as } \\
\text { used in the NACP RCIS. }\end{array}$ & $\mathrm{PREC} / \mathrm{L}^{5}$ & Zeng et al. (2000) \\
\hline WaSSI & $\begin{array}{l}\text { Runoff is the sum of overland lateral flow, subsurface, and } \\
\text { groundwater flow by an empirical method. }\end{array}$ & PRISM $^{2}$ & Sun et al. (2011) \\
\hline GLDAS & \multirow{2}{*}{$\begin{array}{l}\text { Sum of surface and subsurface runoff. Surface runoff is a function of } \\
\text { infiltration capacity and excess precipitation (non-evaporated inflow } \\
\text { in excess of storage capacity by layer). Subsurface runoff is a linear } \\
\text { function of subsurface moisture content above a minimum threshold. } \\
\text { Runoff is simulated using the Noah version } 2.8 \text { land surface model as } \\
\text { implemented in GLDAS-2 (Rodell et al., 2004) and NLDAS-2 (Xia et } \\
\text { al., 2012). }\end{array}$} & Princeton $^{6}$ & \multirow{2}{*}{$\begin{array}{l}\text { Ek et al. (2003); } \\
\text { Schaake et al. (1996) }\end{array}$} \\
\hline NLDAS & & $\begin{array}{l}\text { gauge-only } \mathrm{CPC}^{7} \\
\text { (orographic adjust- } \\
\text { ment using PRISM) }\end{array}$ & \\
\hline NARR & $\begin{array}{l}\text { Sum of surface and subsurface runoff. Surface runoff is a function of } \\
\text { infiltration capacity and excess precipitation (non-evaporated inflow } \\
\text { in excess of storage capacity by layer). Subsurface runoff is a linear } \\
\text { function of subsurface moisture content above a minimum threshold. } \\
\text { Water budget does not close due to assimilation of precipitation and } \\
\text { snow. }\end{array}$ & \multirow[t]{3}{*}{-} & \multirow{3}{*}{$\begin{array}{l}\text { Mesinger et al. (2006); } \\
\text { Schaake et al. (1996) }\end{array}$} \\
\hline NARR [GPCP] & $\begin{array}{l}\text { Scaled NARR precipitation (rescaled GPCP }{ }^{4} \text { v } 2.1 \text { data) minus NARR } \\
\text { evapotranspiration. Rescaling aggregates all NARR grid cell values } \\
\text { within a given } 2.5^{\circ} \mathrm{GPCP} \text { grid cell to area-averaged monthly values. } \\
\text { These values are then linearly rescaled to monthly GPCP } \\
\text { precipitation. }\end{array}$ & & \\
\hline NARR [P-E] & NARR precipitation minus NARR evapotranspiration & & \\
\hline MERRA & \multirow{2}{*}{$\begin{array}{l}\text { Sum of precipitation and spurious water source (non-zero due to land- } \\
\text { atmosphere interface inconsistencies) minus evapotranspiration and } \\
\text { changes in surface and sub-surface water (including interception } \\
\text { reservoir, soil moisture, and snow) }\end{array}$} & \multirow{2}{*}{ - } & \multirow{2}{*}{$\begin{array}{l}\text { Koster et al. (2000); } \\
\text { Rienecker et al. (2011) }\end{array}$} \\
\hline MERRA LAND & & & \\
\hline UDel & $\begin{array}{l}\text { Precipitation minus evapotranspiration (from a modified Thornthwaite } \\
\text { water-budget equation) }\end{array}$ & - & Willmott et al. (1985) \\
\hline
\end{tabular}


Princeton - Princeton Forcing Dataset (Sheffield et al., 2006; http://hydrology.princeton.edu/data.php)

${ }^{7}$ gauge-only CPC - Climate Prediction Center (Xie \& Arkin, 1996; http://ftp.cpc.ncep.noaa.gov/precip/CPC UNI PRCP/)

Figures Captions

Figure 1. CONUS water resource regions. USGS water resource regions and major rivers in the CONUS domain. Prior to aggregation of product runoff, regions coverage converted from polygon (http://water.usgs.gov/GIS/huc.html) to $1^{\circ}$ raster using the region with the maximum area of overlap for each grid cell.

Figure 2. Mean CONUS runoff, adjusted runoff, runoff normalized by precipitation, and precipitation. USGS precipitation is based on GPCC, an independent product (not used elsewhere). Adjusted runoff is runoff multiplied by the ratio of forcing precipitation by a standard precipitation reference, GPCC. Data values are mean 2001 to 2005 value, water year basis (cross) and individual years (circles). Color coding denotes product type: USGS stream gauge observations (black), TBMs (blue), reanalyses (red), and the UDel surface station based product (green). NARR variants are: NARR [GPCP]; NARR precipitation scaled to GPCP minus NARR precipitation, and NARR [P-E]; NARR precipitation minus NARR evapotranspiration.

Figure 3. Relative bias in runoff by water resource region and data product. Relative bias is calculated as $(y-y) / y$ where $y$ is USGS stream gauge runoff for a given region averaged over 2001 to 2005 (water year basis) and $\hat{y}$ is the corresponding simulated value. Red denotes underestimation; blue overestimation. Color range is bound by -1 to 7 to accommodate the lower limit of relative bias (-1) and its positive skew. Off-scale values are Rio Grande: NARR [P-E] (10), NARR [GPCP] (11) and Lower Colorado: NARR [P-E] (10), NARR [GPCP] (10), UDel (8). NARR variants are: NARR [GPCP]; NARR precipitation scaled to GPCP minus NARR precipitation, and NARR [P-E]; NARR precipitation minus NARR evapotranspiration.

Figure 4. Relative bias by water use. Relative bias is calculated as $(\hat{y}-y) / y$ where $y$ is USGS stream gauge runoff for the 2005 calendar year (corrected to naturalized flow) and $\hat{y}$ is the corresponding simulated value. Water use is a dimensionless index of net withdrawals normalized by corrected USGS runoff. Each circle represents one CONUS water resource region (inset label for index $>0.05$ only) by product. The Lower Colorado, Rio Grande, and Upper Colorado differ by less than 0.01 in water use index. Circle color coding denotes product type: TBMs (blue), reanalyses (red), and the UDel surface station based product (green). Thick lines (loess smooth) shows increase in relative bias with increasing water use by product type: TBMs (blue), reanalyses -including UDel- (red), and all products (black). Thin red horizontal line is zero bias reference line. NARR variants are: NARR [GPCP]; NARR precipitation scaled to GPCP minus NARR precipitation, and NARR [P-E]; NARR precipitation minus NARR evapotranspiration.

Figure 5. Estimated and observed corrected mean runoff for 2005 only. Depleted flows from USGS are corrected to naturalized flow by adding back net withdrawals in each of the 18 CONUS water resource regions. Estimated runoff product and Nash-Sutcliffe efficiency (NSE) given in upper-left of each panel. NARR variants are: NARR [GPCP]; NARR precipitation scaled to GPCP minus NARR precipitation, and NARR [P-E]; NARR precipitation minus NARR evapotranspiration. Each circle represents the 2001 to 2005 (water year basis) mean for 
one of the 18 CONUS water resource regions. Mean is average across all 14 products by WRR.

619 Symbol size is proportional to net withdrawals by region (i.e., larger symbols indicate larger net 620 withdrawals relative to corrected USGS runoff). Symbol color coding denotes geography: 621 eastern (green), from the Souris-Red-Rainy, Upper Mississippi, and Lower Mississippi regions 622 eastward or numbers 1 to 9, and western (blue) regions, from the Missouri, Arkansas-White-Red, 623 and Texas-Gulf regions westward or numbers 10 to 18. The Lower Colorado and Rio Grande are 624 colored red and have the highest ratios (in excess of 0.4 ) of net withdrawals to corrected flow. 625 Plus sign shows CONUS-wide runoff.

626

627

628

629

630

631

632

633

634

635

636

637

638

639

Figure 6. Spatial patterns of runoff. Maps show monthly mean runoff and its coefficient of variation (mean/standard deviation in \%) by grid cell from 2001 to 2005 (water year basis). Difference maps show runoff difference (left; terrestrial biosphere model mean minus the reanalysis product mean) and relative difference (right; runoff difference normalized by the mean across all 13 gridded products). Reanalysis includes all seven reanalysis products and UDel. WaSSI is not included as its output is catchment-scale and not gridded.

Figure 7. Variability in TBM estimates. Variability is defined as range normalized by mean value expressed as a percentage. Inset numbers: number of NACP RCIS TBMs evaluated. Bar labels refer to variable (upper label: ecosystem respiration $\left[\mathrm{R}_{\mathrm{e}}\right]$; heterotrophic respiration $\left[\mathrm{R}_{\text {het }}\right]$; gross primary productivity [GPP]) and spatial domain (lower label: contiguous United States [CONUS]; grid cells co-located with flux towers across the North American domain [FLUXNET]; full North American domain [NA]). 


\section{Appendix}

643 Table A1. Mean runoff (mm/yr) from 2001 to 2005 (water year basis) and water use (2005 644 calendar year only) by water resource region (WRR). Water use expressed as an index; the ratio of gross or net withdrawals (taken from Caldwell et al., 2012) to USGS depleted runoff.

\begin{tabular}{|c|c|c|c|c|c|c|c|c|c|c|c|c|c|c|c|c|c|}
\hline \multirow[b]{2}{*}{ WRR } & \multicolumn{15}{|c|}{ Product } & \multicolumn{2}{|c|}{ Water Use } \\
\hline & $\sum_{\substack{\text { 至 } \\
0}}$ & $\frac{\bar{a}}{\bar{a}}$ & $\bar{z}$ & कृ & $\begin{array}{l}\overrightarrow{5} \\
\text { Dे } \\
\tilde{N}\end{array}$ & 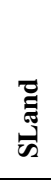 & 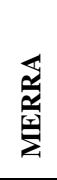 & 党 & 产 & 总突 & 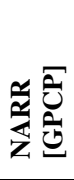 & $\frac{n}{3}$ & 党 & $\begin{array}{l}\bar{\Phi} \\
\text { 界 }\end{array}$ & $\begin{array}{l}0 \\
0 \\
0 \\
0\end{array}$ & 焉 & 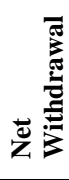 \\
\hline New England & 339 & 598 & 312 & 623 & 548 & 811 & 263 & 236 & 254 & 309 & 606 & 595 & 399 & 545 & 580 & 0.05 & 0.01 \\
\hline Mid-Atlantic & 307 & 459 & 378 & 486 & 520 & 689 & 205 & 273 & 166 & 292 & 448 & 604 & 373 & 506 & 528 & 0.23 & 0.02 \\
\hline $\begin{array}{l}\text { South Atlantic- } \\
\text { Gulf }\end{array}$ & 352 & 541 & 339 & 561 & 403 & 652 & 130 & $24 \mathrm{C}$ & 139 & 345 & 552 & 471 & 519 & 518 & 423 & 0.17 & 0.03 \\
\hline Great Lakes & 285 & 295 & 170 & 339 & 363 & 497 & 59 & 87 & 101 & 171 & 371 & 458 & 160 & 351 & 335 & 0.37 & 0.02 \\
\hline Ohio & 397 & 501 & 391 & 470 & 538 & 715 & 152 & 232 & 159 & 337 & 424 & 567 & 414 & 541 & 516 & 0.20 & 0.01 \\
\hline Tennessee & 489 & 659 & 512 & 563 & 570 & 899 & 259 & 366 & 136 & 388 & 518 & 626 & 606 & 713 & 605 & 0.27 & 0.01 \\
\hline Upper Mississippi & 184 & 234 & 203 & 282 & 273 & 444 & 16 & 40 & 80 & 210 & 293 & 354 & 125 & 298 & 225 & 0.33 & 0.03 \\
\hline Lower Mississippi & 534 & 655 & 459 & 637 & 571 & 792 & 168 & 428 & 215 & 489 & 673 & 567 & 480 & 717 & 520 & 0.25 & 0.11 \\
\hline Souris-Red-Rainy & 61 & 119 & 92 & 180 & 123 & 312 & 7 & 16 & 38 & 113 & 191 & 199 & 48 & 134 & 82 & 0.09 & 0.03 \\
\hline Missouri & 71 & 60 & 102 & 116 & 75 & 171 & 8 & 16 & 50 & 103 & 125 & 118 & 18 & 123 & 46 & 0.88 & 0.36 \\
\hline $\begin{array}{l}\text { Arkansas-White- } \\
\text { Red }\end{array}$ & 162 & 185 & 195 & 220 & 166 & 286 & 32 & 65 & 57 & 230 & 261 & 222 & 103 & 270 & 56 & 0.63 & 0.34 \\
\hline Texas-Gulf & 166 & 234 & 207 & 300 & 184 & 257 & 44 & 11 & 60 & 261 & 359 & 190 & 133 & 293 & 66 & 0.78 & 0.41 \\
\hline Rio Grande & 26 & 26 & 50 & 72 & 12 & 36 & 5 & $\varepsilon$ & 49 & 97 & 115 & 75 & 9 & 74 & 9 & 2.47 & 1.25 \\
\hline Upper Colorado & 26 & 38 & 95 & 76 & 44 & 100 & 10 & 12 & 185 & 94 & 79 & 139 & 12 & 105 & 37 & 1.00 & 0.37 \\
\hline Lower Colorado & 26 & 16 & 34 & 63 & 12 & 20 & 3 & 2 & 14 & 95 & 96 & 53 & 14 & 78 & 8 & 3.39 & 1.97 \\
\hline Great Basin & 34 & 35 & 53 & 87 & 23 & 53 & 10 & s & 85 & 81 & 94 & 84 & 24 & 103 & 32 & 0.67 & 0.36 \\
\hline Pacific Northwest & 299 & 232 & 387 & 297 & 381 & 348 & 125 & 162 & 303 & 343 & 345 & 392 & 156 & 323 & 278 & 0.22 & 0.08 \\
\hline California & 237 & 271 & 280 & 220 & 184 & 270 & 117 & 130 & 189 & 310 & 351 & 264 & 173 & 313 & 199 & 0.64 & 0.42 \\
\hline
\end{tabular}

646

647

648

649
Figure A1. Spatial patterns of runoff. Maps show monthly mean runoff by product (alphabetical from left to right) and grid cell from 2001 to 2005 (water year basis). USGS and WaSSI are not displayed as these products are catchment-scale and not gridded. 


\section{$651 \quad$ Figures}

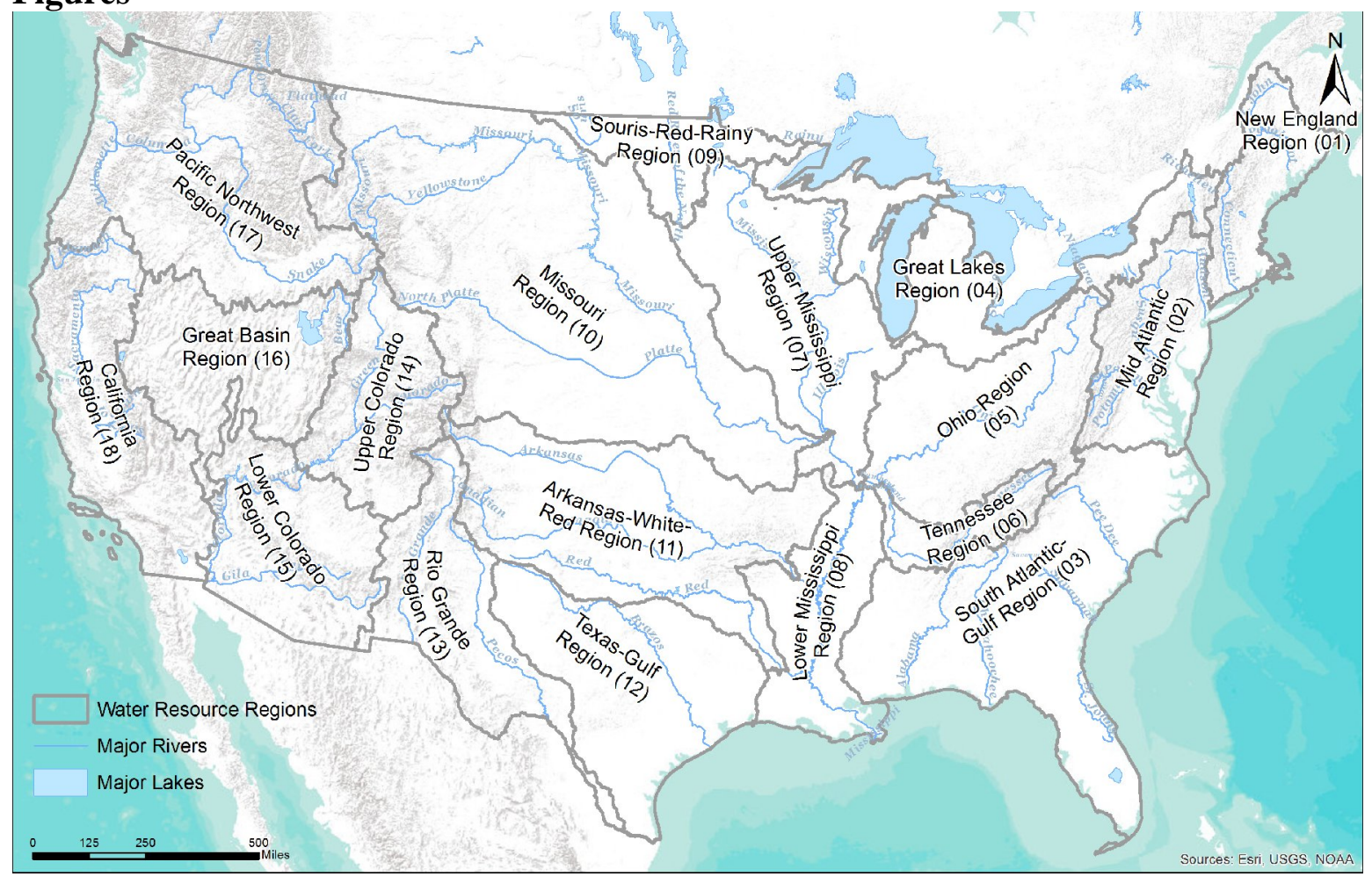

653 Figure 1 
654

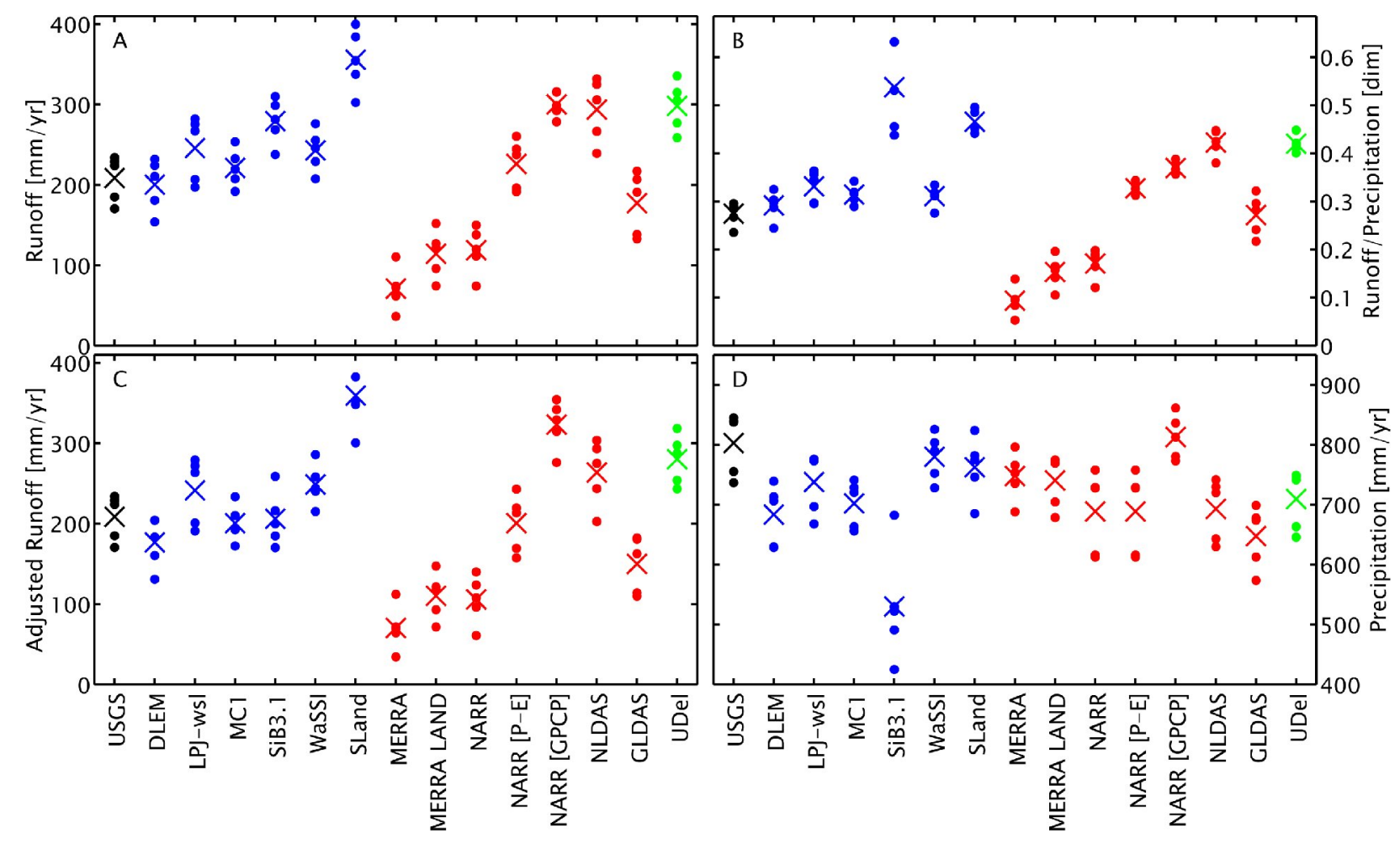

655

Figure 2 


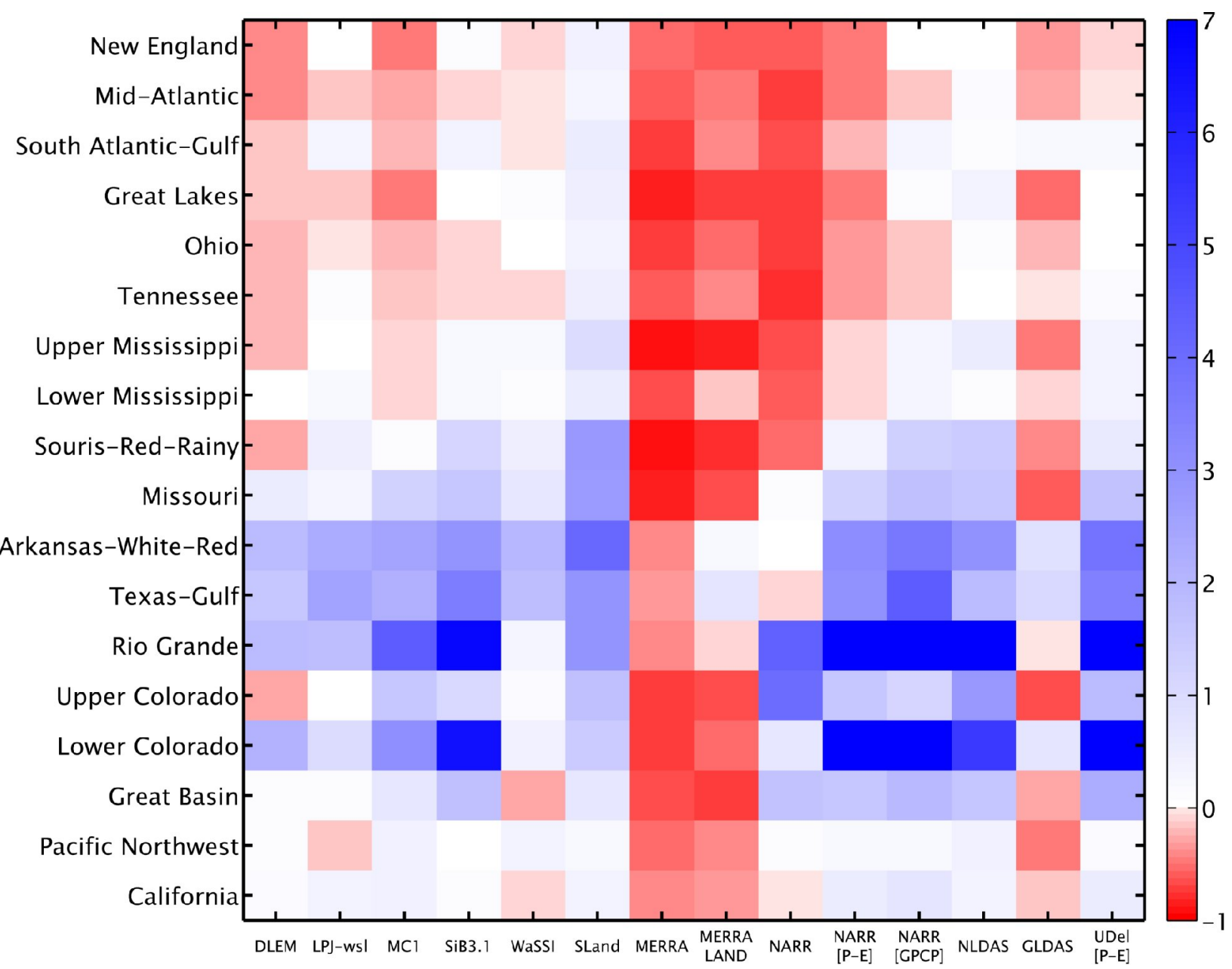

659 Figure 3 
660

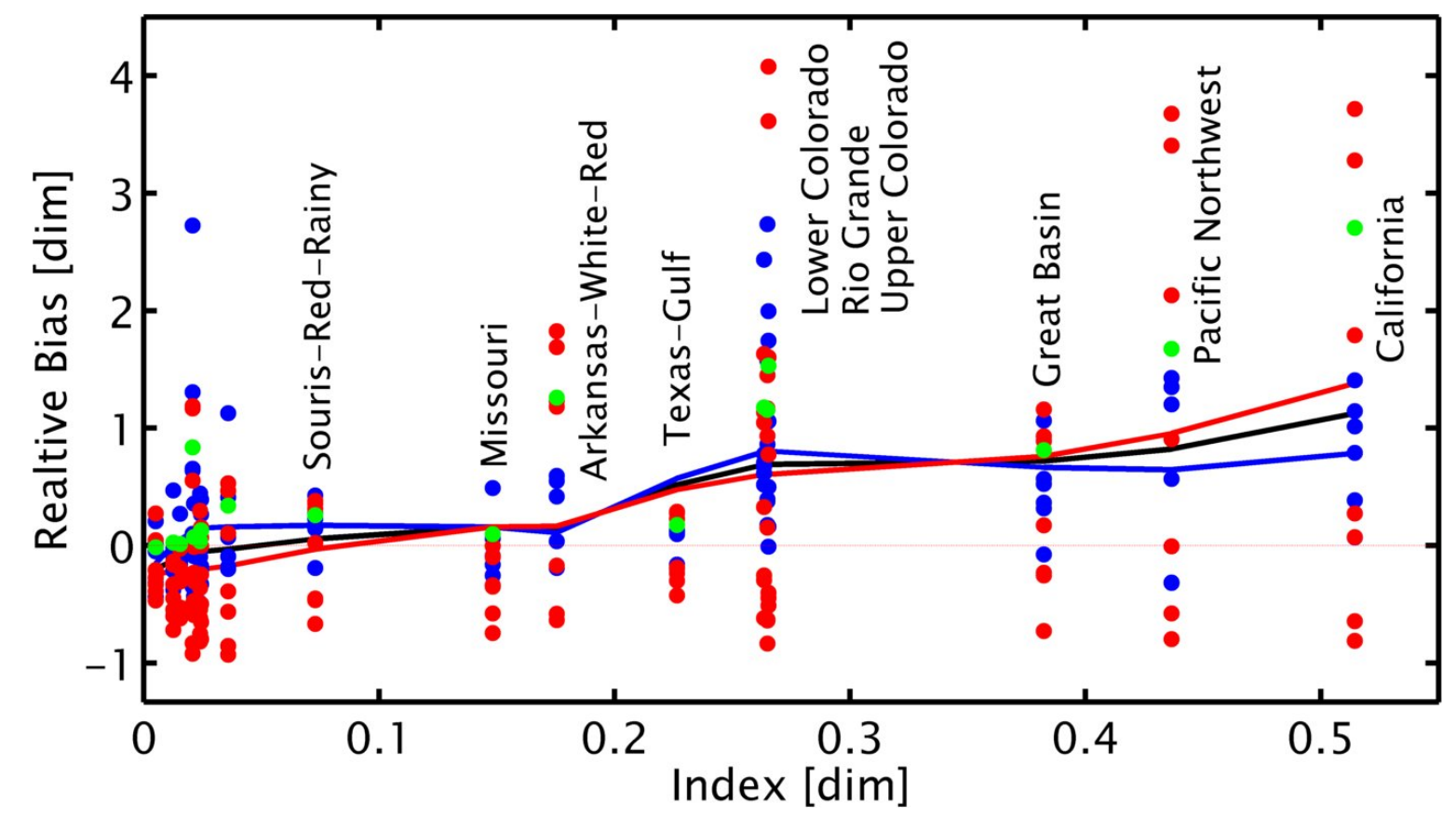

662 Figure 4

663 

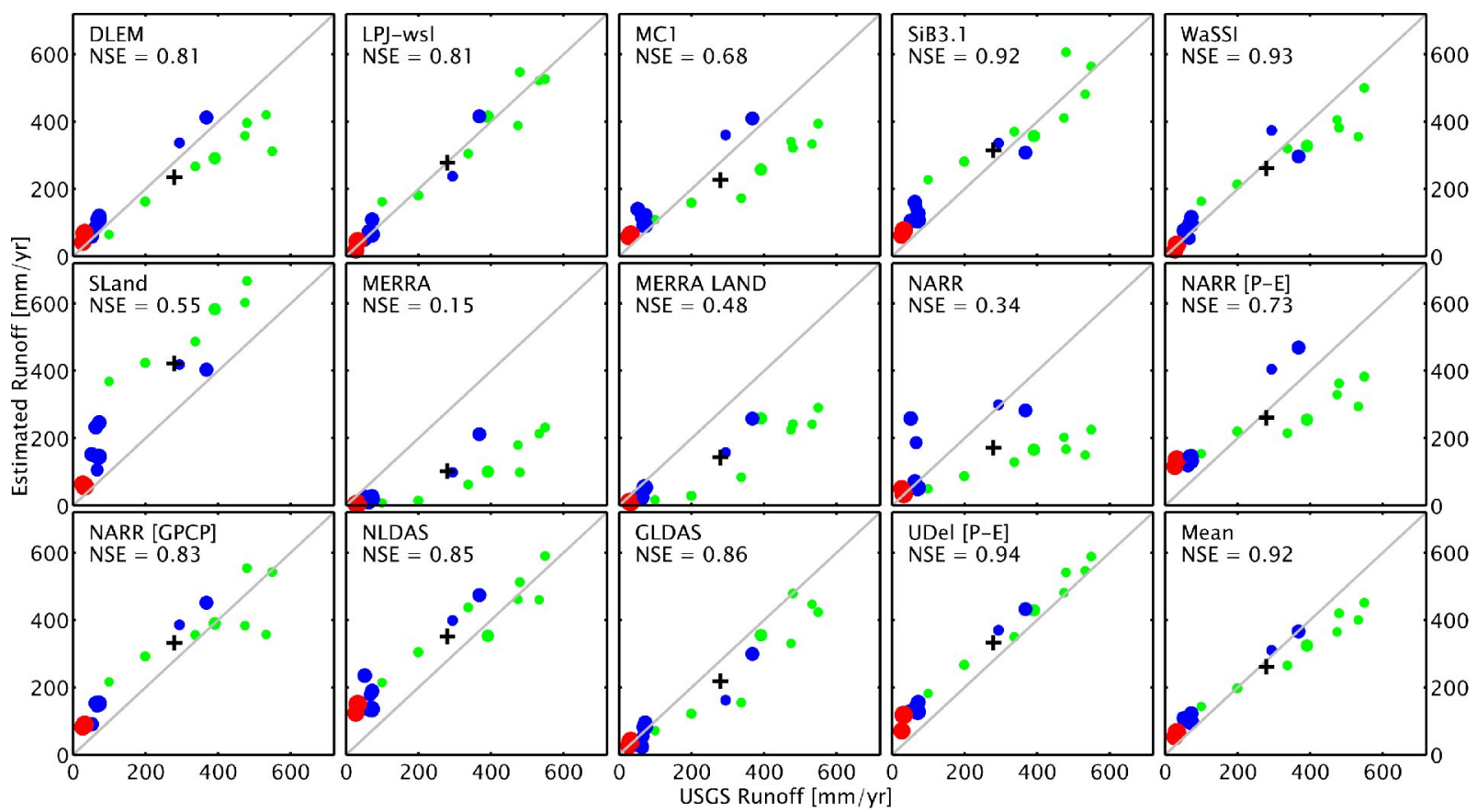

666

Figure 5 

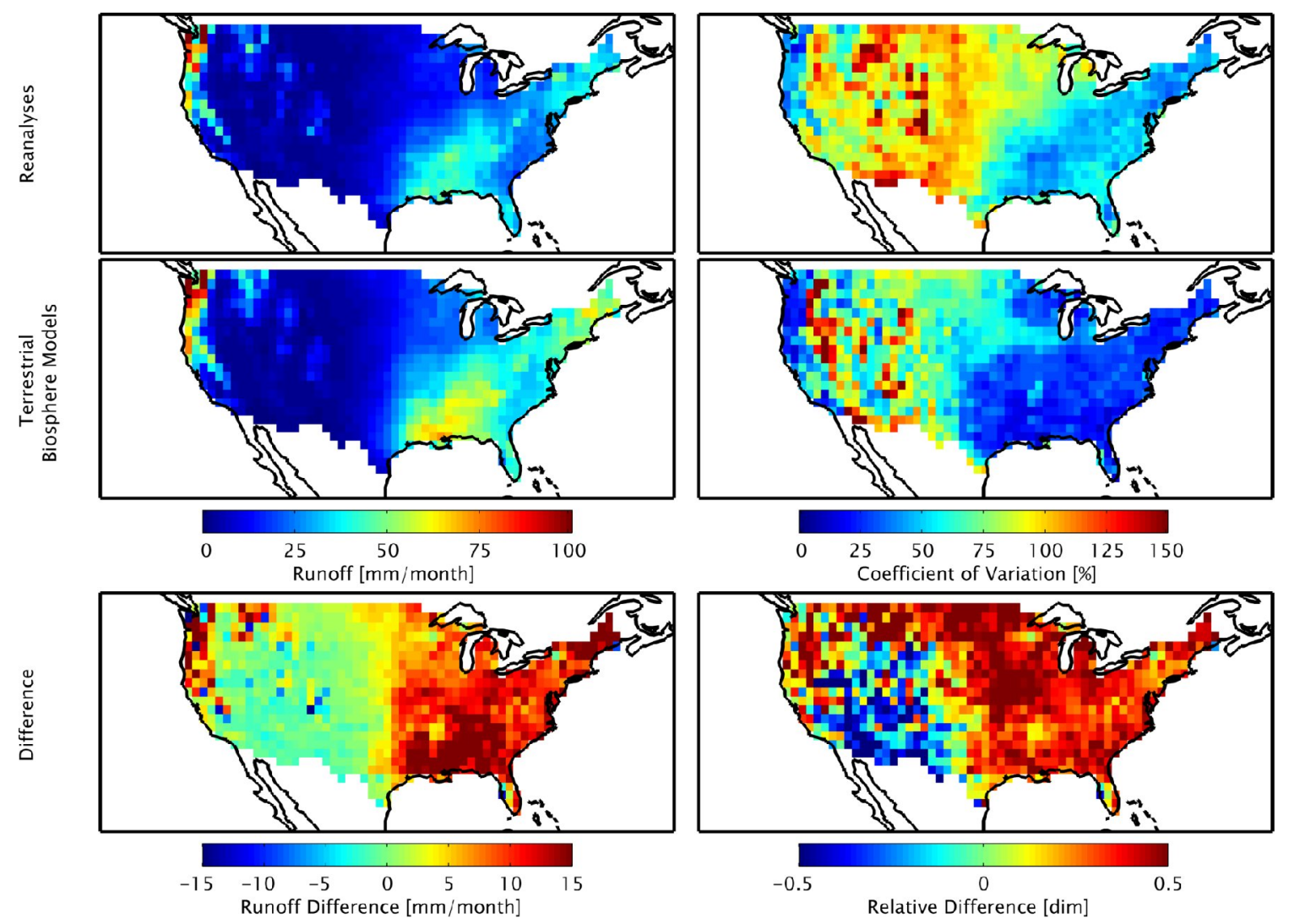

669

Figure 6 
671

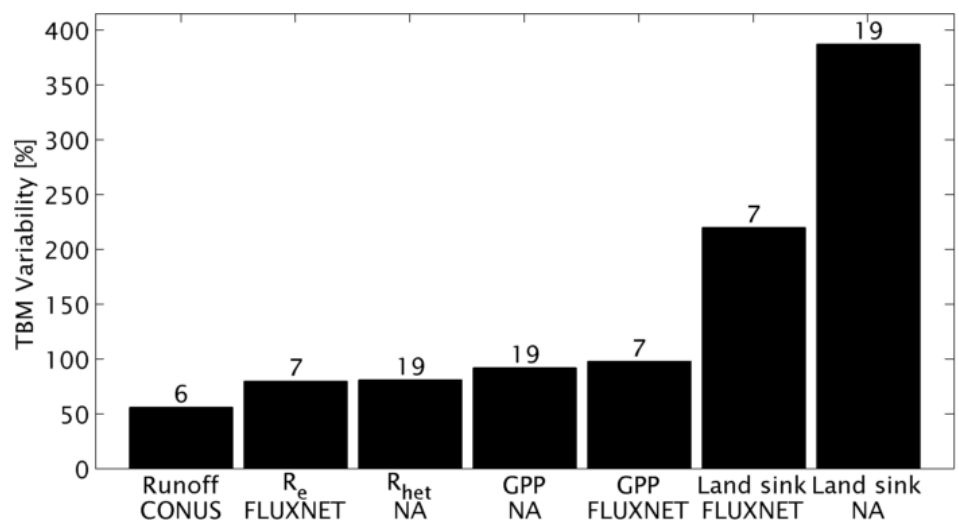

$673 \quad$ Figure 7 
674
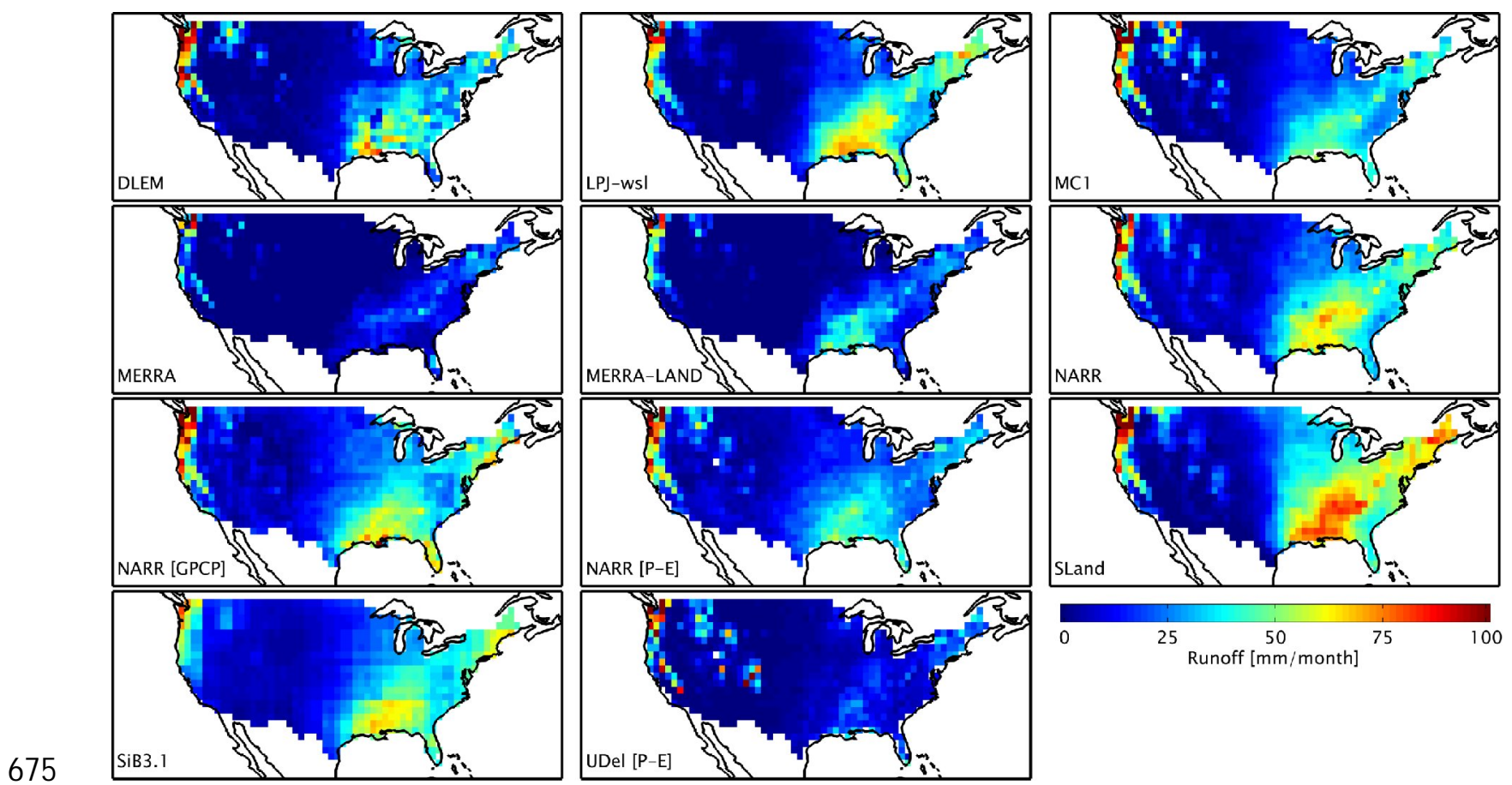

676 Figure A1

677 